DOI:

UDC 621.746.4:669.13

V.V. Kaverinsky, Ph.D., senior researcher, hisie@ukr.net

G.A. Bagluk, Prof. dr., deputy director, gbag@ukr.net

V.Ya. Kurovsky, researcher, kurovskyi@bigmir.net

\title{
MODELING OF IN-MOLD PLACED MG-CONTAINING MODIFIER BRIQUETTES MELTING DURING PIG-IRON CASTING
}

Computer simulation methods were used to analyze the effect of the shape of magnesiumcontaining modifier briquettes placed in the gating system on the time of their melting. Modeling of hydrodynamics of the flow of liquid metal and thermal conductivity was carried out by the finite element method. As the material of castings, pre-eutectic cast iron is adopted, which is poured into rectangular plates into a sand mold.

Keywords: in-mold modification; cast iron; pressed briquette; computer modeling; finite element method.

Методи комп'ютерного моделювання використовувалися для аналізу впливу форми магнієвмісних модифікаторів, щуо розміщені в литниковій системі, на час їх плавлення. Моделювання гідродинаміки потоку рідкого металу і теплопровідності проводили методом скінченних елементів. В якості матеріалу виливків приймався доевтектичний чавун, який розливався в прямокутні плити в піщану форму.

Ключові слова: модифікування in-mold; чавун; пресований брикет; комп'ютерне моделювання; метод скінченних елементів.

\section{Introduction}

Modification of a cast iron melt for to spherical graphite inclusions obtaining is a modern and effective (in sense of obtained mechanical properties) technology. Such cast iron is called highstrength. It could be obtained by modifying with additives $(0.1 \ldots 0.5 \% \mathrm{Mg}, 0.2 \ldots 0.3 \% \mathrm{Ce}, \mathrm{Y}$ and some other elements). Before the modifiers inlet it is necessary to reduce the sulfur content to $0.02 \ldots 0.03 \%$. The recommended chemical composition of high-strength cast iron $(2.7 \ldots 3.7 \% \mathrm{C}$, $0.5 \ldots 3.8 \% \mathrm{Si}$ ) is selected depending on the thickness of the casting product (the thinner the wall, the more carbon and silicon should be contained) [1]. High-strength cast iron has good casting and consumer properties: machinability, cutting ability, high wear resistance, etc. It can be useful for massive castings instead of steel casting or forged parts for such details as cylinders, gears, crankshafts and camshafts, etc. The technologies for high-stress iron modification are an actual, actively developing direction. Many modifiers for cast iron contain $\mathrm{Mg}$, which facilitates the globularization of graphite inclusions. This is inherently a modifier of the first kind, which has long become a universally recognized.

Existing methods of bucket spheroidizing modification involve the usage of special flow charts for placing a modifier, for example a reaction pocket for the modifier on the bottom of the ladle, additional equipment for filling the ladle with molten iron, such as a lid-tank with a hole for storing the molten iron and dosed its feeding into the ladle, forklift for removing and putting the lid on the ladle $[2-4]$.

Magnesium for cast iron modification is used in ligatures form. For example, in [5] the following compositions of ligatures are presented: silicon 22.0 - 30.0; magnesium 9.0-12.0; cerium $0.4-$ 0.6 ; copper - the rest; and silicon 22.0-30.0; magnesium 9.0-12.0; misch metal 0.8-1.2; copper - the rest. The research center for JSC AVTOVAZ developed a technology for ladle modification of high-strength cast iron using a "heavy" Ni-Mg-Ce-ligature [6]. The peculiarity of this ligature is its higher density in comparison with the density of the melt, which makes it possible to carry out modification without the use of special devices and equipment.

Due to the high heat of fusion of silicon which is 4 ...6 times higher than the heat of fusion of magnesium and other components of the modifier, the use of lumpy ferrosilicon is associated with a 
significant consumption of electricity (up to $1500 \mathrm{kWh}$ ) and losses of ferrosilicon during its preparation. The melting point of ferrosilicon is $100-150^{\circ} \mathrm{C}$ higher than the boiling point of magnesium, so the fusion of these components is characterized by high fire and explosion hazard [7].

The technology of in-mold process has become widespread in the world practice of the production of castings, especially in large-scale and mass production [8]. During casting, cast iron, passing through the pour system and interacts with the modifier in it. Thus, the modification reaction takes place in an enclosed space. The absence of direct contact with the external environment facilitates the process without pyroeffect and smoke emissions, which improves the working conditions. The assimilation of magnesium when in-mold modification reaches up to $80 \%$ [8]. One of the most effective forms of modification in a form is called the flot-ret method. According to this technique, the original cast iron is poured through a special reactor into which the necessary amount of the modifier is previously placed.

An effective form of the magnesium-containing ligature production is its compacting as briquettes by the powder metallurgy method. Powders of iron, copper and magnesium could be included in the mix of briquettes. Such types of briquettes were used for the iron casting at the Kushvinsky plant of rolling rolls [9].

A method of intraform modification is known [10], characterized in that the metal being poured consistently passes all the channels of the runner system, including the reaction chamber, and then enters the mold cavity. Passing through the reaction chamber, the entire melt is subjected to the same modifying treatment. This is a positive factor for this method.

\section{Material and methodic of the research}

In this work we simulated a technology of in-mold modification in which an annular briquette is placed in the reaction chamber. The chemical composition of the pig iron adopted in the simulation is shown in table 1 below. Table 2 shows the chemical composition of briquettes.

Table 1. Chemical composition of pig iron (wt. \%)

\begin{tabular}{|c|c|c|c|c|c|c|}
\hline $\mathrm{Fe}$ & $\mathrm{C}$ & $\mathrm{Si}$ & $\mathrm{Mg}$ & $\mathrm{Cr}$ & $\mathrm{Ni}$ & $\mathrm{P}$ \\
\hline base & 3,27 & 1,86 & 0,68 & 0,12 & 0,33 & 0,12 \\
\hline
\end{tabular}

Table 2. Chemical composition of the modifier briquettes of (wt. \%)

\begin{tabular}{|c|c|c|}
\hline $\mathrm{Cu}$ & $\mathrm{Fe}$ & $\mathrm{Mg}$ \\
\hline 50,0 & 43,0 & 7,0 \\
\hline
\end{tabular}

The thermo-physical properties of the iron in the liquid and solid state are given in table 3 , the properties of the molding soil (sand) in table 4, and the estimated properties of the briquette in a hypothetical, non-porous state are in table 5. The effect of porosity was calculated using formula (1) from [11].

The formula (1) for thermal conductivity values recalculating with allowance for porosity is given below:

$$
\lambda_{\ni \phi .}=\lambda_{0} \cdot(1-\theta) \cdot\left(1+\frac{1}{2} \cdot \theta\right)^{-1},
$$

where $\lambda_{0}$ - dense material thermal conductivity coefficient, $\mathrm{W} / \mathrm{m} \cdot \mathrm{K} ; \theta$ - volume fraction of pores in the material.

The estimated values of the liquidus and solidus temperatures for pig iron of this composition are respectively $1248{ }^{\circ} \mathrm{C}$ and $961{ }^{\circ} \mathrm{C}$. The conditional liquidus and solidus temperatures of the briquette were taken, respectively $1433^{\circ} \mathrm{C}$ (estimated liquidus temperature of an alloy which consists of $50 \% \mathrm{Cu}, 43 \% \mathrm{Fe}, 7 \% \mathrm{Mg}$ ) and $630^{\circ} \mathrm{C}$ (melting point $\mathrm{Mg}$ ). 
Table 3. Thermo-physical properties of pig iron in liquid and solid state

\begin{tabular}{|c|c|c|c|c|c|c|}
\hline $\begin{array}{c}\text { Temperature, } \\
{ }^{\circ} \mathrm{C}\end{array}$ & State & $\begin{array}{c}\text { Thermal conduc- } \\
\text { tivity, } \\
\mathrm{W} / \mathrm{m} \cdot \mathrm{K}\end{array}$ & $\begin{array}{l}\text { Specific } \\
\text { heat, } \\
\mathrm{kJ} / \mathrm{kg} \cdot \mathrm{K}\end{array}$ & $\begin{array}{c}\text { Density, } \\
\mathrm{kg} / \mathrm{m}^{3}\end{array}$ & $\begin{array}{l}\text { Equilibrium } \\
\text { part of solid } \\
\text { phase, } \%\end{array}$ & $\begin{array}{l}\text { Viscosity, } \\
\text { sps }\end{array}$ \\
\hline 70 & \multirow{9}{*}{ solid } & 36.4 & 0.686 & 7609 & \multirow{9}{*}{100} & \multirow{9}{*}{ - } \\
\hline 200 & & 35.1 & 0.705 & 7576 & & \\
\hline 300 & & 34.1 & 0.720 & 7540 & & \\
\hline 400 & & 33.1 & 0.735 & 7503 & & \\
\hline 550 & & 31.6 & 0.758 & 7463 & & \\
\hline 650 & & 30.6 & 0.773 & 7422 & & \\
\hline 700 & & 30.1 & 0.780 & 7401 & & \\
\hline 800 & & 29.2 & 0.795 & 7358 & & \\
\hline 900 & & 28.1 & 0.810 & 7229 & & \\
\hline 1000 & \multirow{3}{*}{$\begin{array}{l}\text { liquid }+ \\
\text { solid }\end{array}$} & 15.58 & \multirow{5}{*}{$0.836^{*}$} & 6964 & 37.36 & 9.16 \\
\hline 1100 & & 25.53 & & 6587 & 32.91 & 7.36 \\
\hline 1200 & & 27.40 & & 6464 & 12.33 & 5.41 \\
\hline 1300 & \multirow{2}{*}{ liquid } & 29.71 & & 6344 & 0 & 4.04 \\
\hline 1400 & & 30.80 & & 6257 & 0 & 3.14 \\
\hline
\end{tabular}

Table 4. Thermo-physical properties of a silica sand

\begin{tabular}{|c|c|c|c|}
\hline $\begin{array}{c}\text { Temperature, } \\
{ }^{\circ} \mathrm{C}\end{array}$ & $\begin{array}{c}\text { Thermal conductivity, } \\
\mathrm{W} / \mathrm{m} \cdot \mathrm{K}\end{array}$ & $\begin{array}{c}\text { Specific heat, } \\
\mathrm{kJ} / \mathrm{kg} \cdot \mathrm{K}\end{array}$ & Density, $\mathrm{kg} / \mathrm{m}^{3}$ \\
\hline 25 & 0.73 & 0.68 & \multirow{2}{*}{1520} \\
\hline 200 & 0.64 & 0.91 & \multirow{2}{*}{1520} \\
\hline 400 & 0.59 & 1.05 & \\
\hline 600 & 0.60 & 1.10 & \\
\hline 800 & 0.64 & 1.18 & \\
\hline 1000 & 0.70 & &
\end{tabular}

Table 5. Properties of the briquette material in the solid state *

\begin{tabular}{|c|c|c|c|c|}
\hline Temperature, ${ }^{\circ} \mathrm{C}$ & State & $\begin{array}{c}\text { Thermal conduc- } \\
\text { tivity, } \\
\mathrm{W} / \mathrm{m} \cdot \mathrm{K}\end{array}$ & $\begin{array}{c}\text { Specific heat, } \\
\mathrm{kJ} / \mathrm{kg} \cdot \mathrm{K}\end{array}$ & Density, $\mathrm{kg} / \mathrm{m}^{3}$ \\
\hline 400 & 64.61 & 0.86 & 8190 & 100 \\
\hline 500 & 65.82 & 0.84 & 8169 & 100 \\
\hline 600 & 68.82 & 0.78 & 8107 & 100 \\
\hline 700 & 70.68 & 0.75 & 8046 & 90.0 \\
\hline 800 & 71.21 & 0.72 & 7984 & 85.0 \\
\hline 900 & 70.46 & 0.69 & 7922 & 75.0 \\
\hline 1000 & 68.38 & 0.69 & 7860 & 56.0 \\
\hline 1100 & 65.07 & 0.68 & 7797 & 55,8 \\
\hline 1200 & 60.62 & 0.68 & 7733 & 54,7 \\
\hline 1300 & 55.00 & 0.68 & 7665 & 52,6 \\
\hline
\end{tabular}

* — for the liquid state, the properties were assumed to be the same as for the main melt

The castings shape is plate $200 \times 100 \times 20 \mathrm{~mm}$. The height of the sprue is $700 \mathrm{~mm}$, and its diameter is $20 \mathrm{~mm}$. The length of the horizontal runner is $145 \mathrm{~mm}$ with diameter of $16 \mathrm{~mm}$. The total height of the vertical part of the runner and the reaction chamber, in which the briquette is placed is 
$115 \mathrm{~mm}$, the height of the chamber it self is $70 \mathrm{~mm}$, the diameters of the inlet and outlet holes in the chamber are $16 \mathrm{~mm}$. The following shapes of briquettes with a modifier are the next: one with a conical channel whish outer diameter $40 \mathrm{~mm}$, its height is $20 \mathrm{~mm}$, upper bore diameter is $20 \mathrm{~mm}$ and lower bore diameter is $34 \mathrm{~mm}$ (hereinafter - shape-1); one with a cylindrical channel, outer diameter is $40 \mathrm{~mm}$, height $20 \mathrm{~mm}$ and hole diameter $24 \mathrm{~mm}$ (hereinafter - form-2); one with a cylindrical channel, outer diameter $40 \mathrm{~mm}$, height $30 \mathrm{~mm}$, hole diameter $29 \mathrm{~mm}$ (hereinafter - form-3); one with a cylindrical channel, outer diameter $40 \mathrm{~mm}$, height $15 \mathrm{~mm}$, hole diameter $18.7 \mathrm{~mm}$ (hereinafter form-4). The briquettes were placed in the middle of the reaction chamber height. The simulation was performed for $10 \%$ porosity level.

The temperature of the inlet metal when casting was assumed to be $1460{ }^{\circ} \mathrm{C}$. The initial temperature of the briquettes and sand was $20^{\circ} \mathrm{C}$. At the boundaries of the sections, the following heat transfer coefficients were established:

- external surface of the mold / ambient air: $10 \mathrm{~W} / \mathrm{m}^{2} \mathrm{~K}$;

- sand / cast iron: $800 \mathrm{~W} / \mathrm{m}^{2} \mathrm{~K}$;

- briquette / cast iron: $5000 \mathrm{~W} / \mathrm{m}^{2} \mathrm{~K}$;

- briquette / sand: $100 \mathrm{~W} / \mathrm{m}^{2} \mathrm{~K}$.

Simulation was a conjugate heat and hydrodynamic calculation. The heat exchange conditions on the surface were specified by the boundary conditions, the heat transfer in the volume was described by the no stationary heat equation (2).

$$
\frac{\partial T}{\partial \tau}=\frac{\lambda}{C \cdot \rho} \cdot\left(\frac{\partial^{2} T}{\partial x^{2}}+\frac{\partial^{2} T}{\partial y^{2}}+\frac{\partial^{2} T}{\partial z^{2}}\right),
$$

where $T$ - temperature, $\mathrm{K} ; \tau$ - time, $\mathrm{s} ; \lambda$ - coefficient of thermal conductivity, $\mathrm{W} / \mathrm{m} \cdot \mathrm{K} ; C$ - heat capacity, $\mathrm{J} / \mathrm{kg} \cdot \mathrm{K} ; \rho$ - density, $\mathrm{kg} / \mathrm{m}^{3} ; x, y, z$ - coordinates, $\mathrm{m}$.

Modeling of hydrodynamics (flow of the melt) was carried out on the basis of the NavierStokes flow equation $(3-6)$.

$$
\begin{gathered}
\frac{\partial v_{x}}{\partial \tau}+v_{x} \frac{\partial v_{x}}{\partial x}+v_{y} \frac{\partial v_{x}}{\partial y}--\frac{1}{\rho} \frac{\partial p}{\partial x}+v\left(\frac{\partial^{2} v_{x}}{\partial x^{2}}+\frac{\partial^{2} v_{x}}{\partial y^{2}}+\frac{\partial^{2} v_{z}}{\partial z^{2}}\right) \\
\frac{\partial v_{y}}{\partial \tau}+v_{x} \frac{\partial v_{y}}{\partial x}+v_{y} \frac{\partial v_{y}}{\partial y}--\frac{1}{\rho} \frac{\partial p}{\partial y}+v\left(\frac{\partial^{2} v_{y}}{\partial x^{2}}+\frac{\partial^{2} v_{y}}{\partial y^{2}}+\frac{\partial^{2} v_{z}}{\partial z^{2}}\right) \\
\frac{\partial v_{z}}{\partial \tau}+v_{x} \frac{\partial v_{z}}{\partial z}+v_{y} \frac{\partial v_{z}}{\partial z}--\frac{1}{\rho} \frac{\partial p}{\partial z}+v\left(\frac{\partial^{2} v_{y}}{\partial x^{2}}+\frac{\partial^{2} v_{y}}{\partial y^{2}}+\frac{\partial^{2} v_{z}}{\partial z^{2}}\right) \\
\frac{\partial v_{x}}{\partial x}+\frac{\partial v_{y}}{\partial y}+\frac{\partial v_{z}}{\partial z}=0
\end{gathered}
$$

where: $\tau$ - time, $\mathrm{s} ; \rho$ - density, $\mathrm{kg} / \mathrm{m}^{3} ; x, y, z$ are the coordinates, $\mathrm{m} ; v_{x}, v_{y}, v_{z}$ - velocity field, $v-$ kinematic viscosity coefficient, $\mathrm{m}^{2} / \mathrm{s}$.

This system has an analytical solution only in certain special cases. However, the problem can be solved numerically. To solve these differential equations, the finite element method was used. This method, which originated from the outset as one of the methods of structural research (strength calculations), is now universally recognized as a general way of solving wide range of problems in various fields of technology. The essence of the method is in the fact that the region (one-, two- or threedimensional) in which the solution of the differential equations is sought is divided into a number of small subdomains that are finite in size. The region of each element, independently of the others, is given its own distribution law for the unknown functions. Such a piecewise-continuous approximation is performed using specially selected approximating functions. Outside of an element, the approximating function is equal to zero. The values of functions on the boundaries of elements (at nodes) are a solution of the problem and are unknown in advance. The coefficients of the approximating functions are sought from the condition that the values of the neighboring functions on the boundaries between 
the elements (at the nodes) are equal. Then these coefficients are expressed in terms of the values of the functions at the nodes of the elements. It is directly proportional to the number of elements and is limited only by the capabilities of the computer. Since each of the elements is associated with a limited number of neighbors, the system of these algebraic equations has a sparse form, which greatly simplifies its solution.

As initial data during modeling, the geometry and cavity of a casting was determined, the location and shape of the briquette, initial temperatures, the direction of gravity, materials of the mold and casted metal, the coefficients of heat transfer between all pairs of geometric elements. Level of the briquettes porosity was set $10 \%$.

\section{Results and discussion}

On the figures $1-3$ and $4-6$ results of the modifier briquette with a conic hole melting in reaction chamber simulation are shown. Figure 1 shows parts of solid and liquid fractions and figure 2 shows temperature fields. As a zero time was set the moment of appearance of metal in the runner.

The simulation shows the next results. The first contact of metal with the modifier briquette occurs after 2.7 seconds from the conditional zero moment. The briquette starts to melt after $1.7 \mathrm{~s}$ from the first contact of liquid iron with it and its melting finishes after 8.3 seconds from the first contact (that is 6.6 after the beginning of melting). The filling of the casting cavity by the moment of the briquette complete melting is $25 \%$. The cavity of the casting start filling after 4.8 seconds from the conditional zero point which is 0.4 seconds from the beginning of the melting of the briquette. The filling of the casting cavity is completed after 28.9 seconds from the conditional zero point (the period of filling is 24.1 seconds). The complete filling of the casting cavity appear after 24.5 seconds from the beginning of the melting of the briquette and 17.9 seconds from the end of its melting. The period of existence of the frozen layer of iron on the briquette surface is from 3.4 to $7.8 \mathrm{~s}$ so it lasts $4.4 \mathrm{~s}$.

The similar calculation experiments were carried out also for other shapes of the modifier briquette described in the part 2 of this article. The brief of the obtained results is shown in table 6.

Table 6. Results of simulation of magnesium containing modifier briquette melting

\begin{tabular}{|c|c|c|c|c|c|c|}
\hline $\begin{array}{l}\text { Briquette } \\
\text { shape, } \\
\text { sec }\end{array}$ & $\begin{array}{l}\text { Start of the } \\
\text { briquette } \\
\text { melting } \\
\text { (from the } \\
\text { first con- } \\
\text { tact with } \\
\text { metal), sec }\end{array}$ & $\begin{array}{l}\text { End of the } \\
\text { briquette } \\
\text { melting } \\
\text { (from the } \\
\text { first con- } \\
\text { tact with } \\
\text { metal), sec }\end{array}$ & $\begin{array}{l}\text { Start filling } \\
\text { the cavity of } \\
\text { the casting } \\
\text { (from the } \\
\text { beginning of } \\
\text { the briquette } \\
\text { melting), } \\
\text { sec }\end{array}$ & $\begin{array}{l}\text { Completion of } \\
\text { the filling of } \\
\text { the casting } \\
\text { cavity (from } \\
\text { the beginning } \\
\text { of the bri- } \\
\text { quette melt- } \\
\text { ing), sec }\end{array}$ & $\begin{array}{l}\text { Completion of } \\
\text { the filling of } \\
\text { the casting } \\
\text { cavity (from } \\
\text { the end of the } \\
\text { briquette } \\
\text { melting), sec }\end{array}$ & $\begin{array}{l}\text { The period of } \\
\text { the frozen } \\
\text { layer exis- } \\
\text { tence (from } \\
\text { the condi- } \\
\text { tional zero } \\
\text { moment), sec }\end{array}$ \\
\hline Shape-1 & 1.7 & 8,3 & 0.4 & 24.5 & 17.9 & $\begin{array}{c}3.4-7.8 \\
(4.4)\end{array}$ \\
\hline Shape-2 & 1.2 & 3.8 & 0.8 & 23.7 & 20.5 & $\begin{array}{c}2.9-4.0 \\
(1.1)\end{array}$ \\
\hline Shape-3 & 0.7 & 3.5 & 1.3 & 24.0 & 21.2 & not noted \\
\hline Shape-4 & 1.9 & 6.4 & 0.5 & 23.5 & 19.0 & $\begin{array}{c}2.4-6.9 \\
(4.5)\end{array}$ \\
\hline
\end{tabular}

From the given data it is seen that the briquette with a conic hole (shape-1) has significantly longer period of melting. Its melting begins at the closest moment to the casting cavity filling beginning and it lasts quite long (6.6 seconds). It also has rather long term of a frozen layer existence (4.4 seconds). But simulation shows that this layer is not continuous and doesn't cower the whole surface during all period of its existence. The result of these facts is that the modifier comes to the iron melt by small portions during its flowing through the reaction chamber and fulfilling of the casting cavity. Thus the distribution of the modifier in the casting volume becomes more uniform then in other cases. 


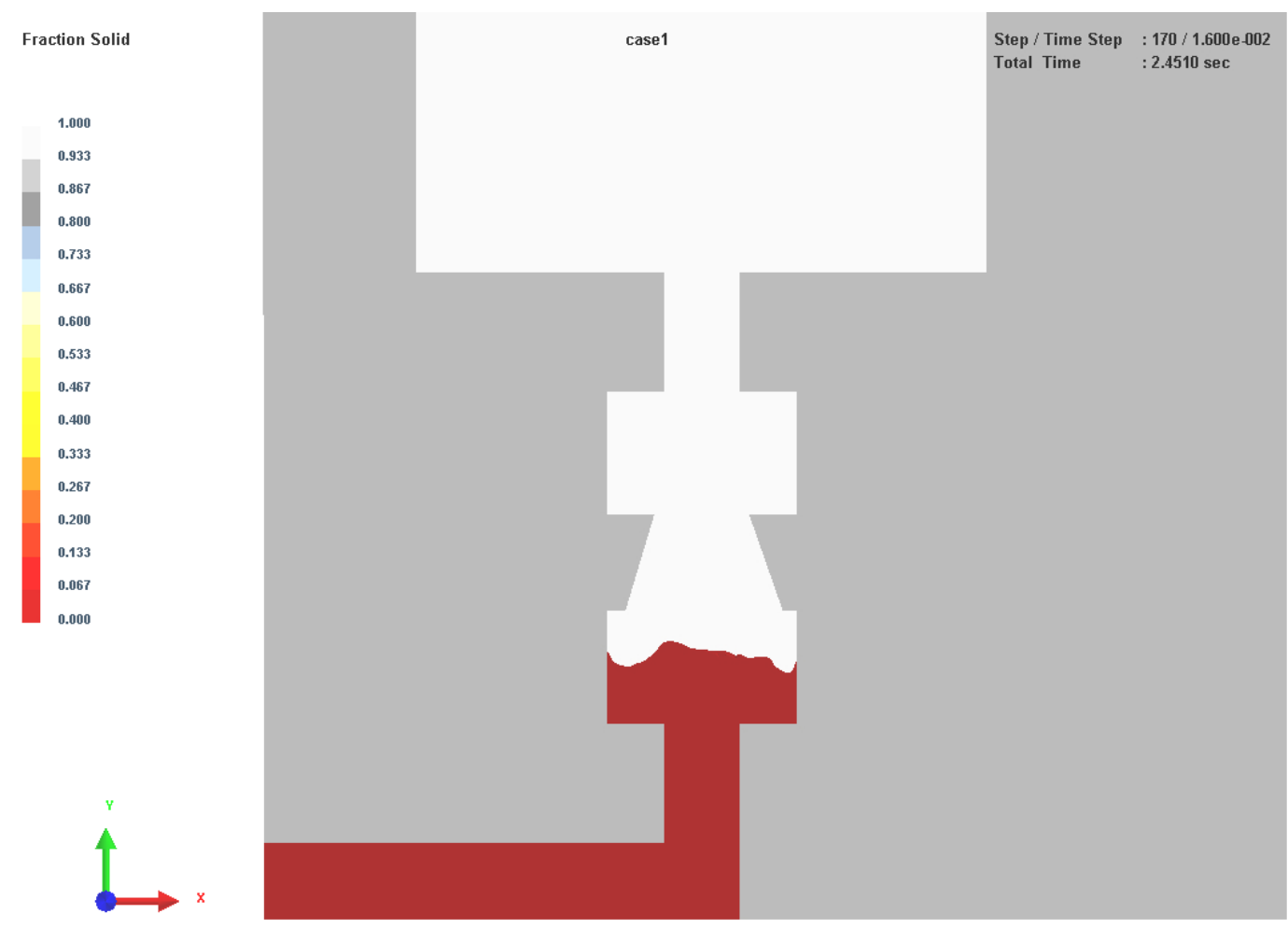

1)
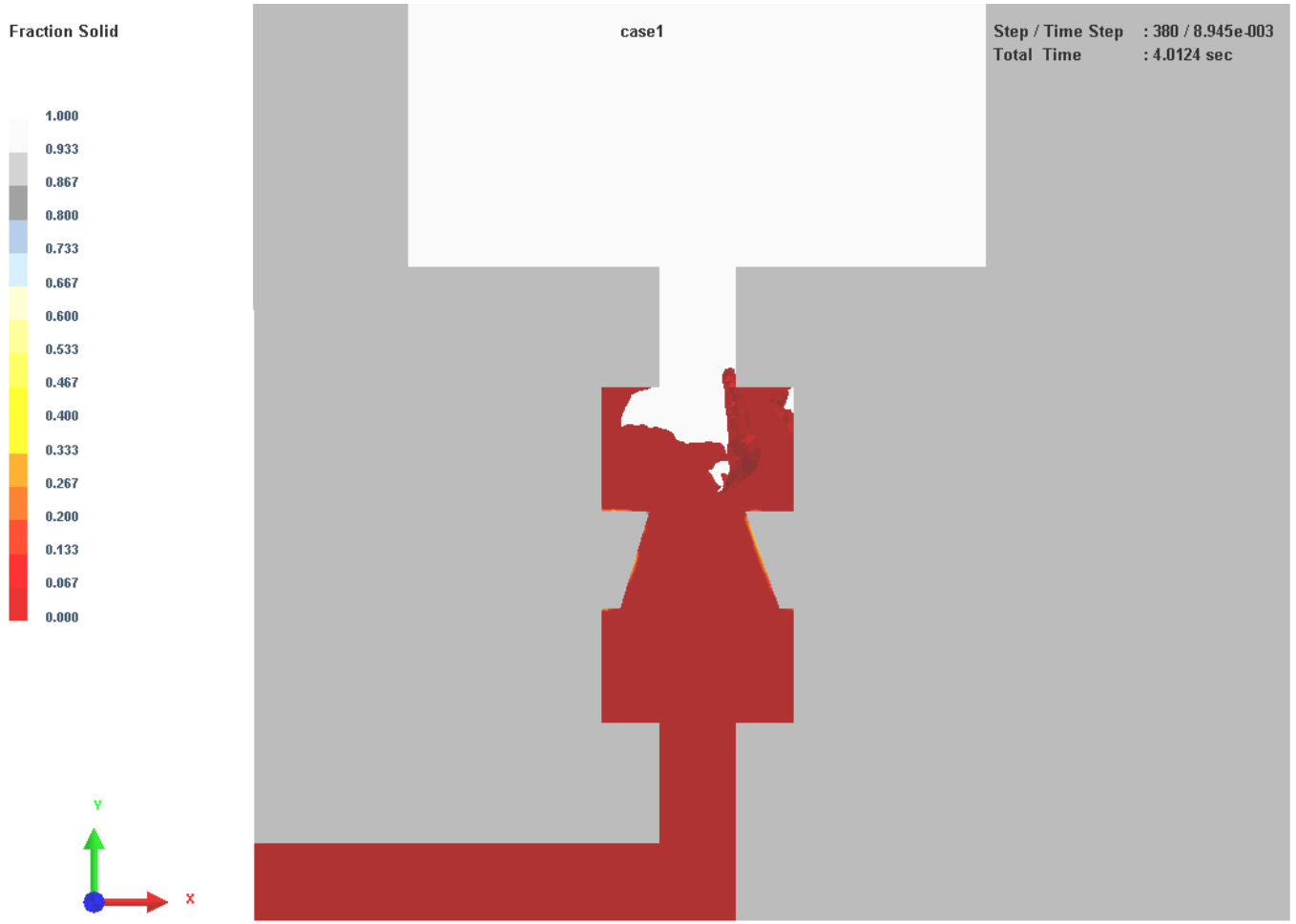

2)

Fig. 1. Illustrations of solid and liquid fractions distribution in a reaction chamber during modifier briquette melting when iron casting during first 4 seconds: 1) after $2.5 \mathrm{sec}$; 2) after $4 \mathrm{sec}$ 

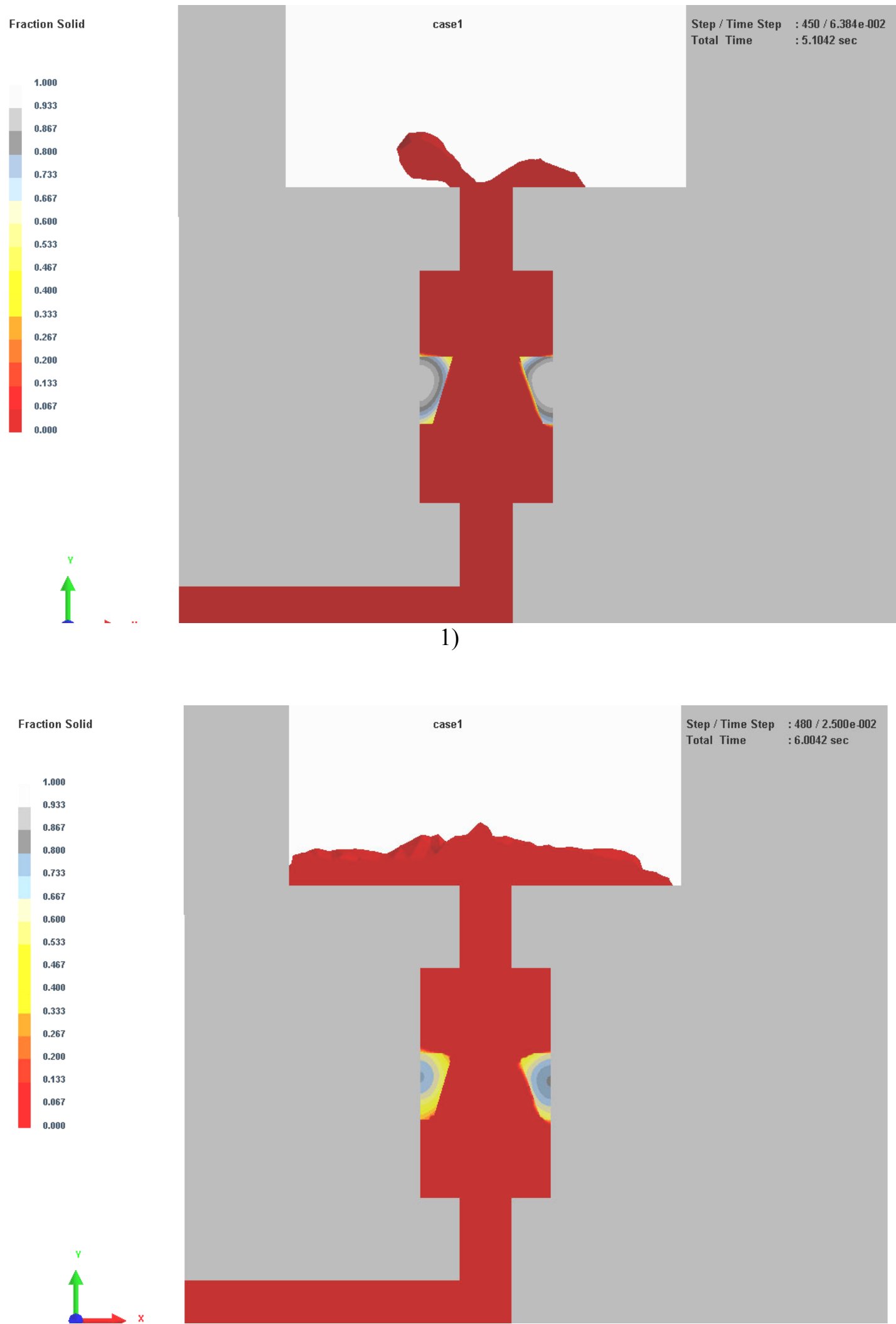

2)

Fig. 2. Illustrations of solid and liquid fractions distribution in a reaction chamber during modifier briquette melting when iron casting during 5.5-6 seconds: 1) after $5.5 \mathrm{sec}$; 2) after $6 \mathrm{sec}$ 


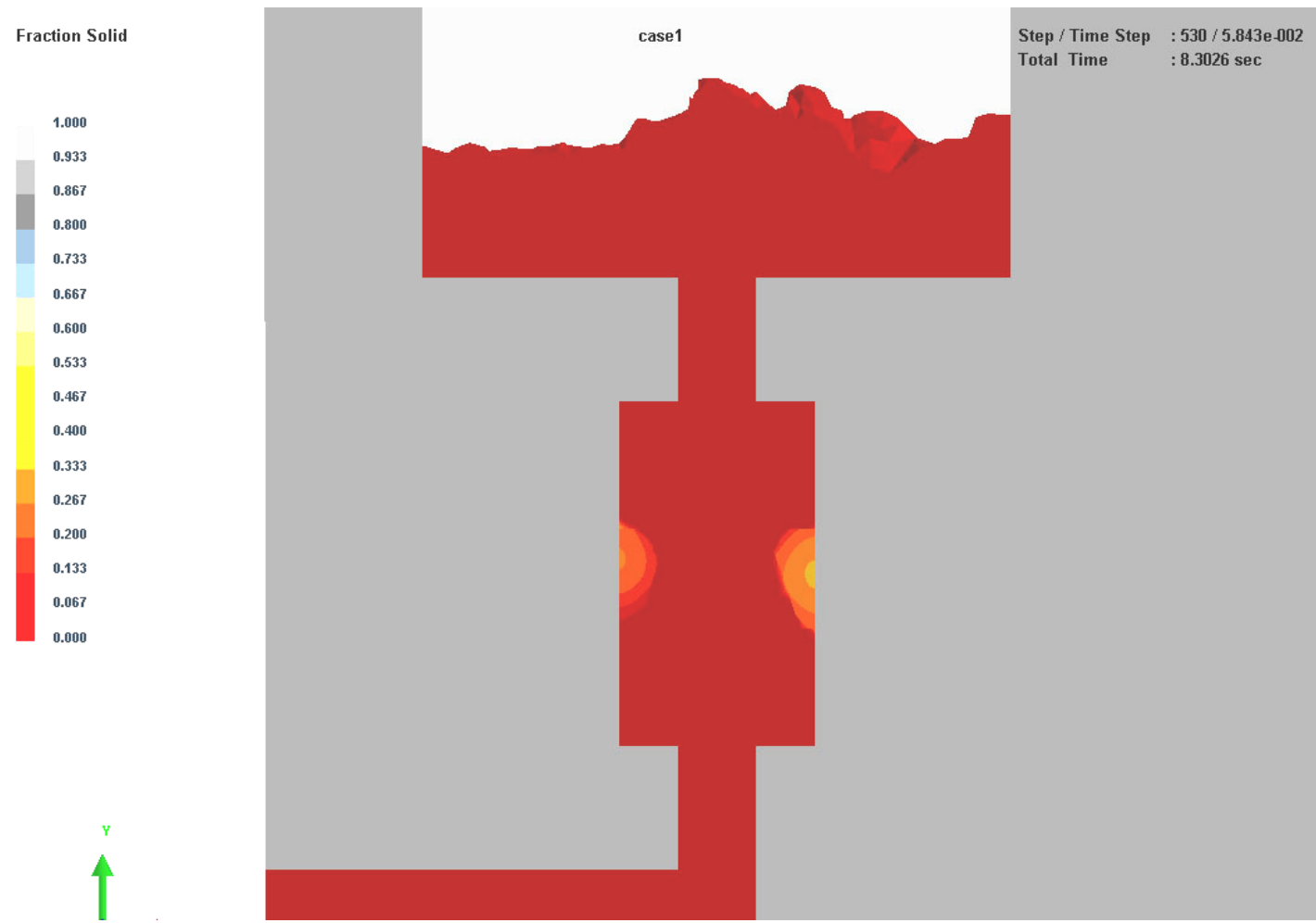

1)

Fraction Solid

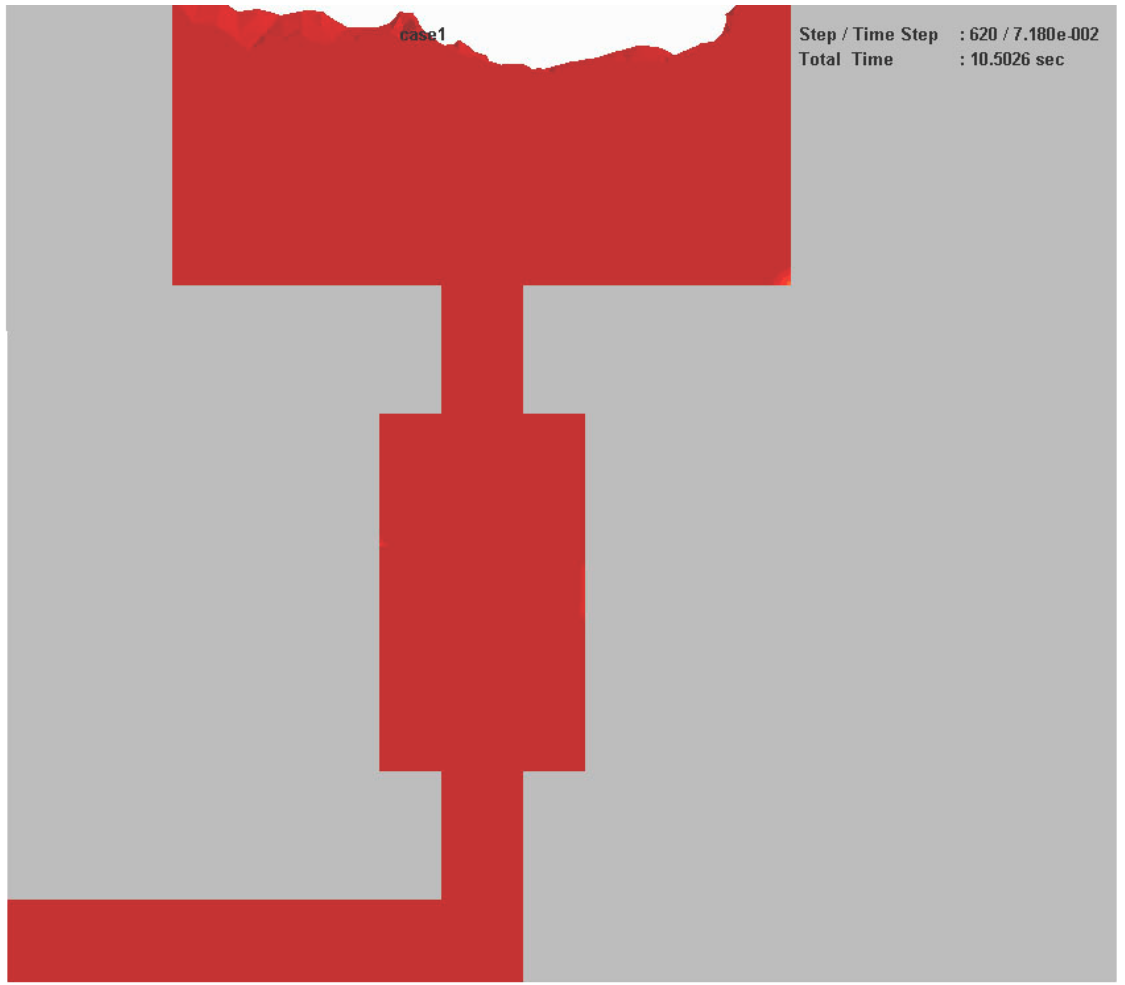

2)

Fig. 3. Illustrations of solid and liquid fractions distribution in a reaction chamber during modifier briquette melting when iron casting during 8-10.5 seconds: 1) after $8 \mathrm{sec}$; 2) after $10.5 \mathrm{sec}$ 


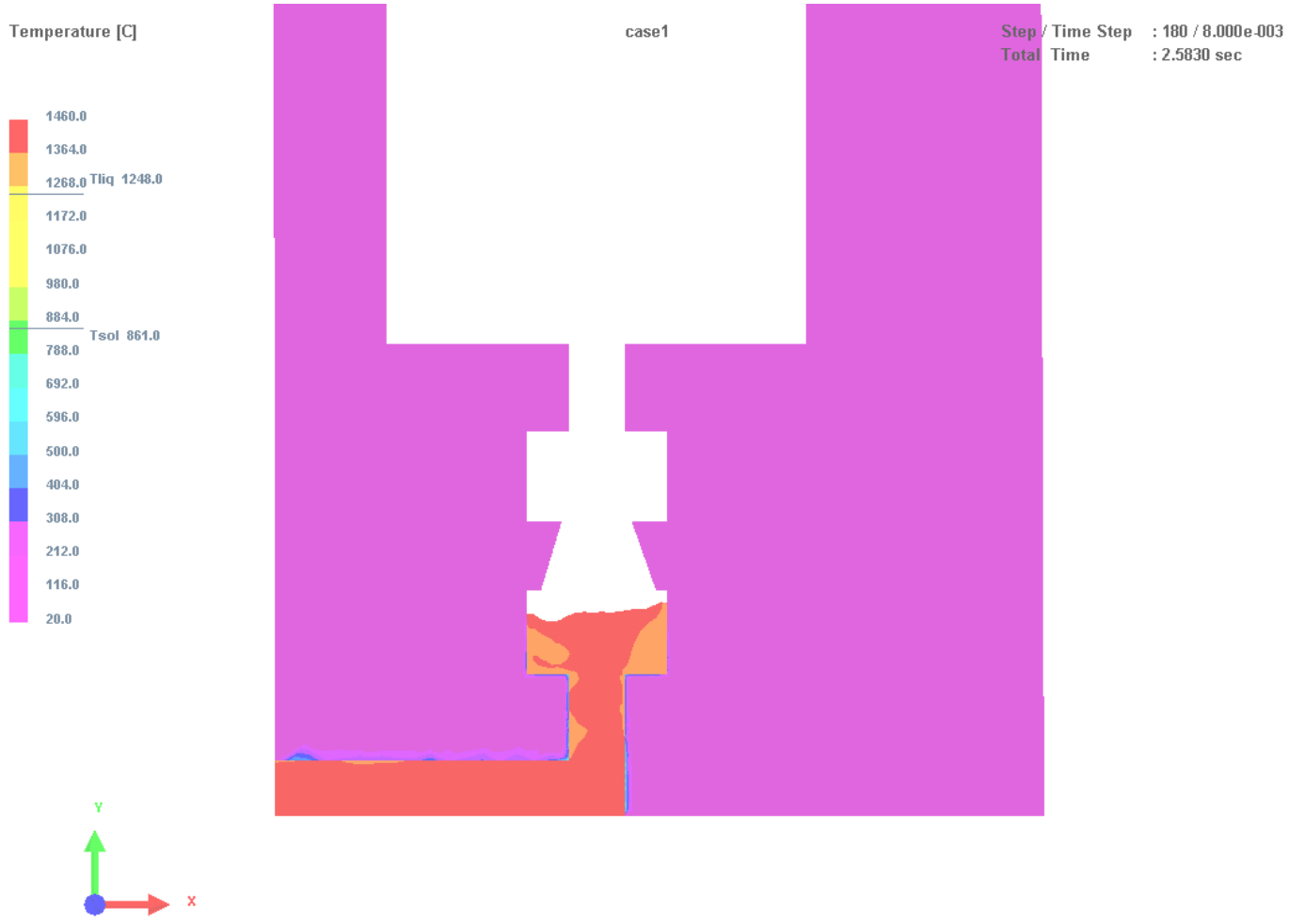

1)

Temperature $[\mathrm{C}]$

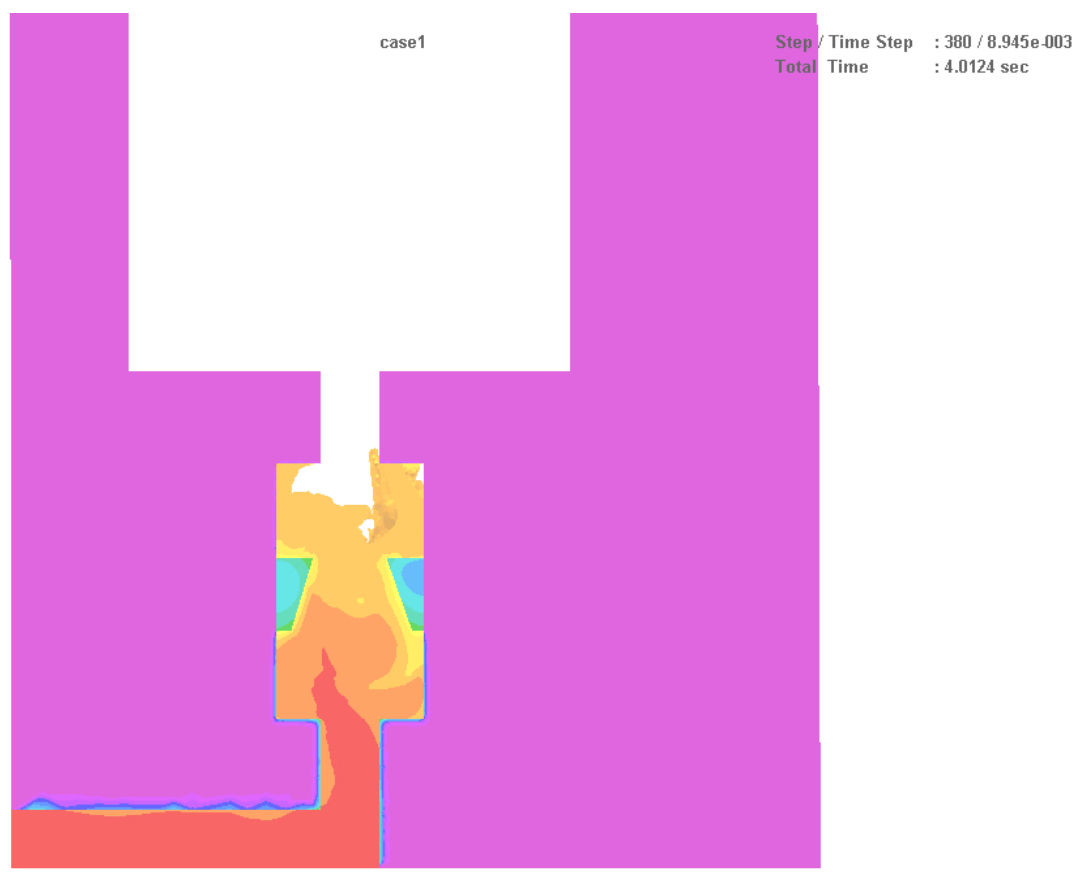

2)

Fig. 4. Illustrations of temperature fields in a reaction chamber and nearing parts of the mold during modifier briquette melting when iron casting during first 4 seconds: 1) after $2.5 \mathrm{sec} ; 2$ ) after $4 \mathrm{sec}$ 

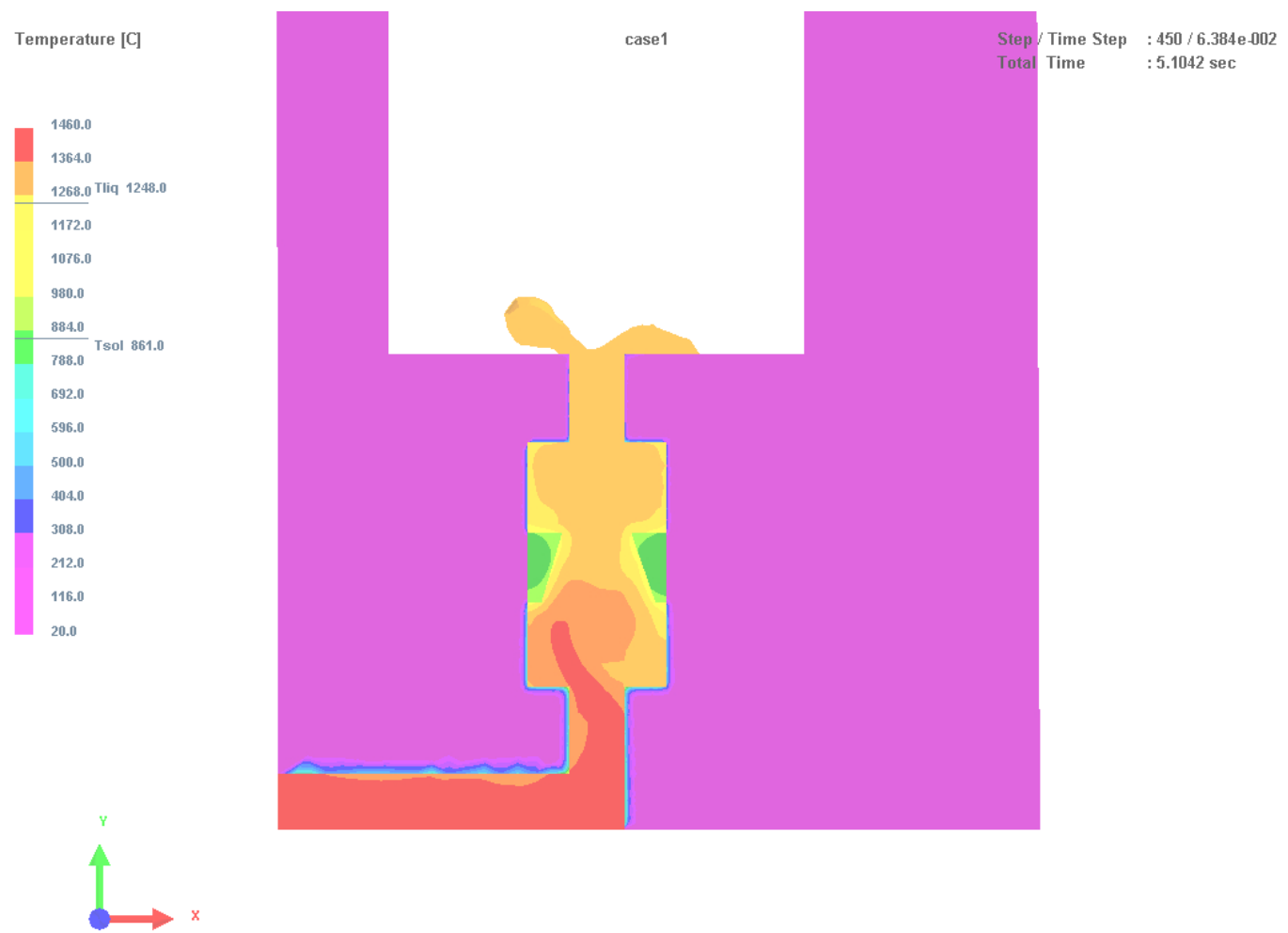

1)

Temperature $[\mathrm{C}]$
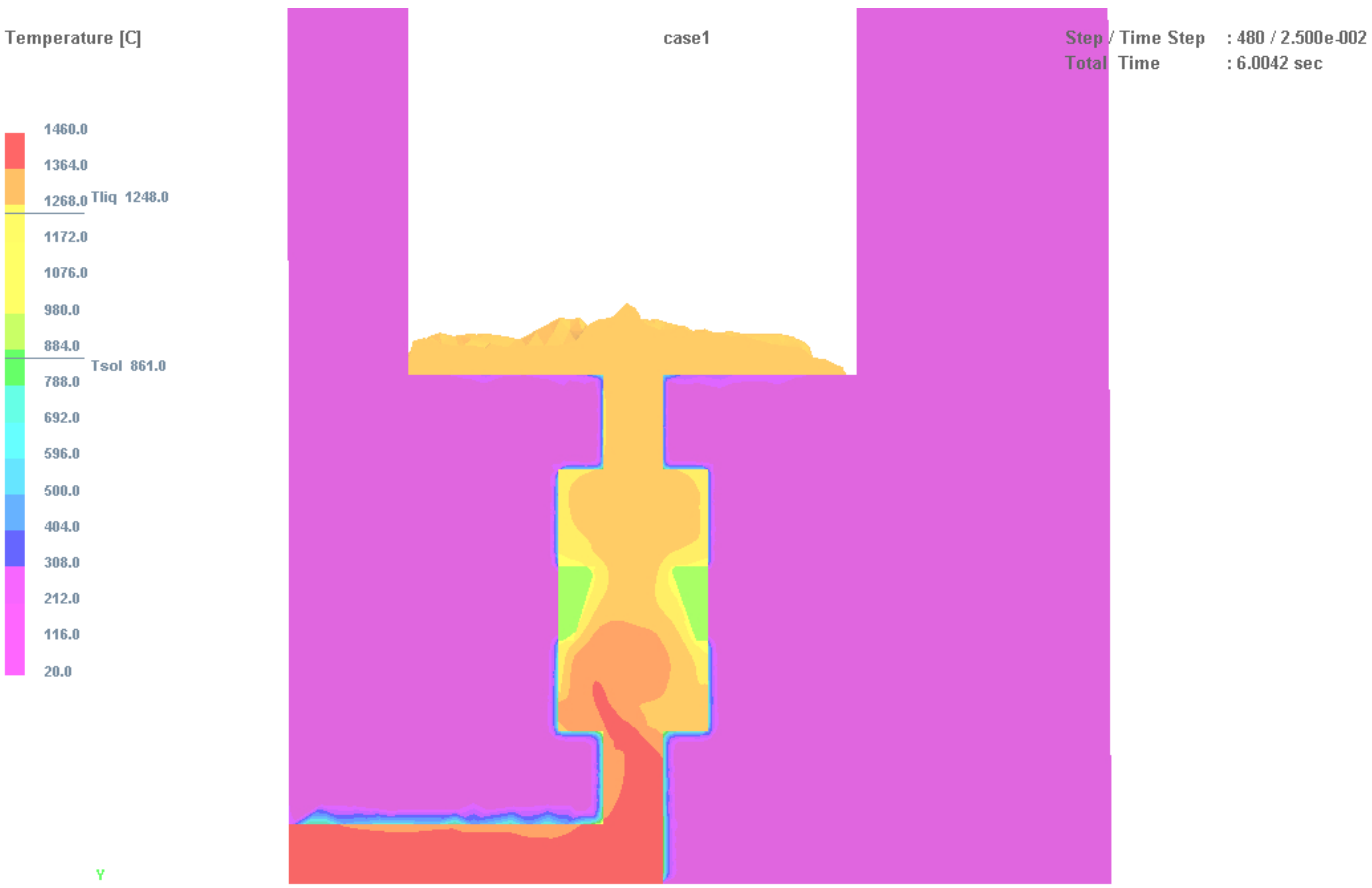

2)

Fig. 5. Illustrations of temperature fields in a reaction chamber and nearing parts of the mold during modifier briquette melting when iron casting during 5.5-6 seconds: 1) after $5 \mathrm{sec}$; 2) after $6 \mathrm{sec}$ 


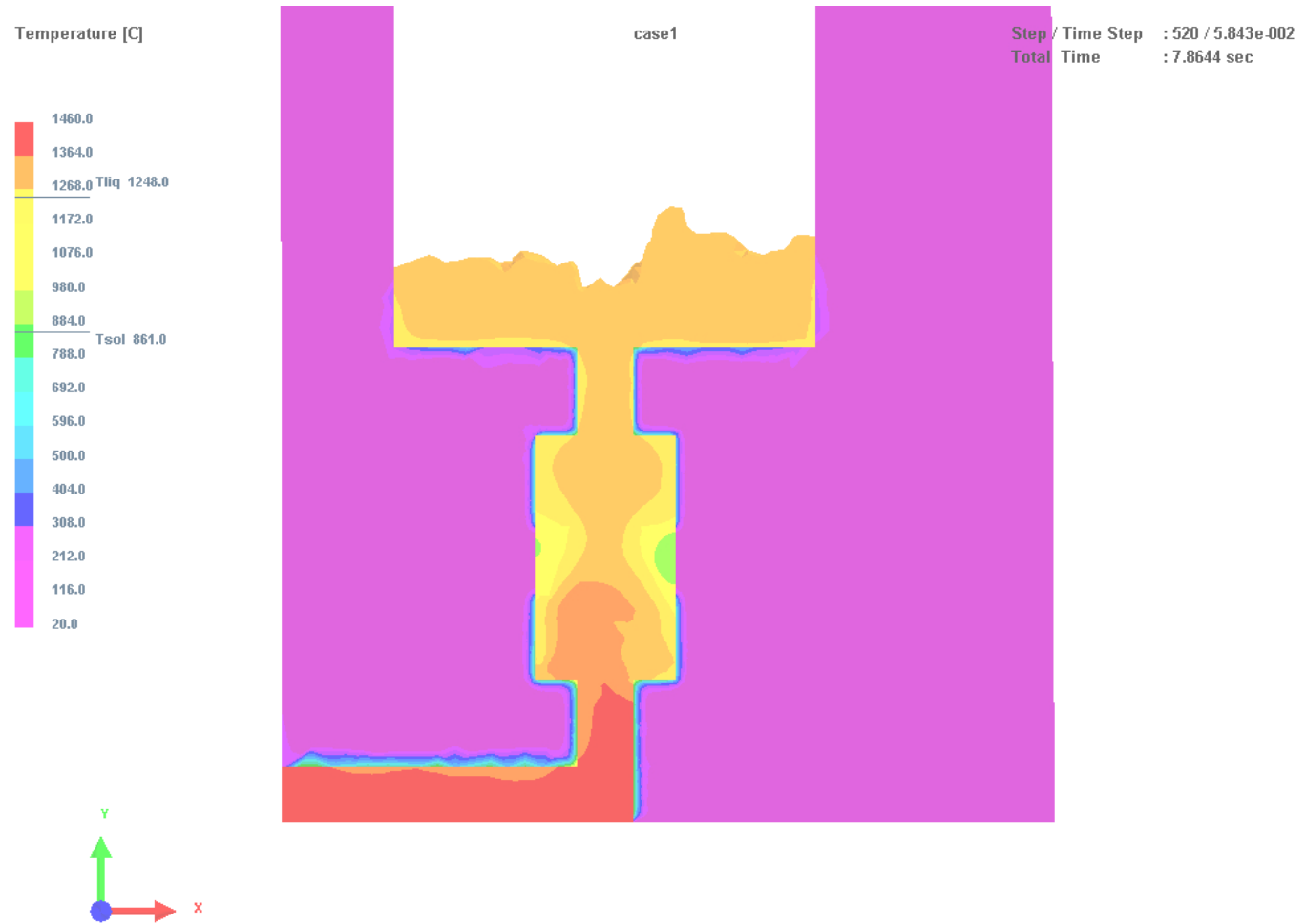

1)

Temperature $[C]$

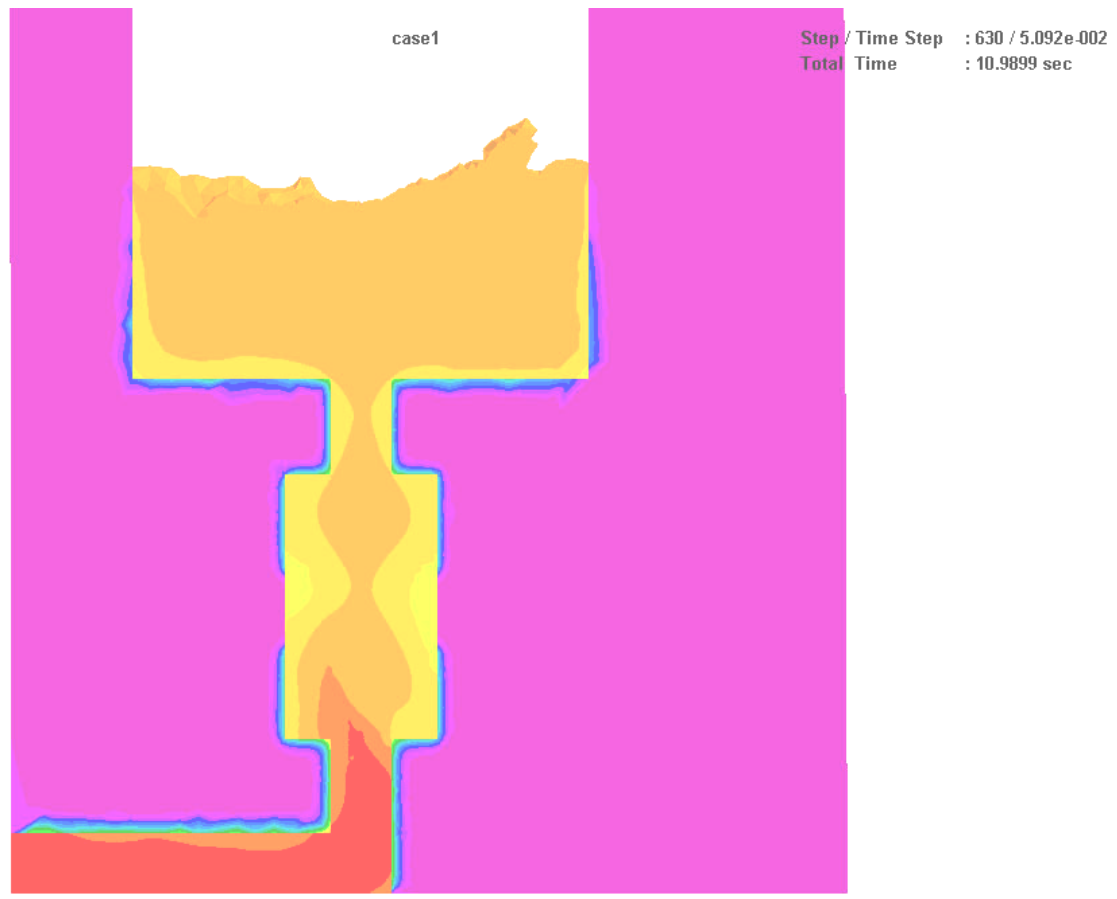

2)

Fig. 6. Illustrations of temperature fields in a reaction chamber and nearing parts of the mold during modifier briquette melting when iron casting during 8-11 seconds: 5) after $8 \mathrm{sec}$; 6) after $11 \mathrm{sec}$ 
Thin briquette (shape-3) becomes to melt very early - after 0.7 seconds. It melts almost without frozen layer according to the simulation. But the process of melting itself lasts rather fast. Rather long period of melting has briquette of shape-4, but it is significantly less then for shape- 1 . Others of their characteristics are quite similar. The behavior of the briquette of shape- 2 is rather similar to one of shape-3: fast period of melting, start of melting very before the casting cavity filling beginning, short period of a frozen layer existence.

The results of simulation proof and explain the obtained experimental data that the shape of the briquette with a conic hole allows to obtain good uniform distribution of the modifier in the casting volume.

\section{Conclusions}

Series of calculation experiments of magnesium containing modifier briquettes melting in a reaction chamber of a casting mold were executed. Four shapes of briquettes were studied. The shapes are the next one with a conical channel whish outer diameter $40 \mathrm{~mm}$, its height is $20 \mathrm{~mm}$, upper bore diameter is $20 \mathrm{~mm}$ and lower bore diameter is $34 \mathrm{~mm}$ (hereinafter - shape-1); one with a cylindrical channel, outer diameter is $40 \mathrm{~mm}$, height $20 \mathrm{~mm}$ and hole diameter $24 \mathrm{~mm}$ (hereinafter - form-2); one with a cylindrical channel, outer diameter $40 \mathrm{~mm}$, height $30 \mathrm{~mm}$, hole diameter $29 \mathrm{~mm}$ (hereinafter - form-3); one with a cylindrical channel, outer diameter $40 \mathrm{~mm}$, height $15 \mathrm{~mm}$, hole diameter $18.7 \mathrm{~mm}$ (hereinafter — form-4).

The simulation shows that the best shape from the investigated ones is shape-1 (briquette of medium height and a conic hole). This is because its long term of melting and a moment of melting start which is very close to the moment of the casting cavity filling beginning. This leads to more uniform distribution of the modifier in the casting volume.

\section{List of reference links}

[1] Rzhevskaya, S.V. (2011). Materialovedenie. Uchebnik dlja vuzov. [Materials Science: A Textbook for Universities]. Moscow: Logos (in Russian).

[2] Knustad O. (2011) Problemy, voznikajushhie pri proizvodstve vysokoprochnyh chugunov. Obzor sushhestvujushhih sposobov poluchenija VCh i ispol'zuemyh modifikatorov [Problems arising in the production of high-strength cast iron. Review of existing methods for obtaining HF and used modifier]. Litejshhik Rossii - The caster of Russia. 4, pp. 19-26 (in Russian).

[3] Kosnikov, G.A. (2002) Osnovy litejnogo proizvodstva [Foundations of Foundry]. St. Petersburg: SPbSPU (in Russian).

[4] Aleksandrov, N.N. (1982) Vysokokachestvennyj chugun dlja otlivok [High-quality cast iron for castings] Moscow: Mashinostroenie (in Russian).

[5] Pat. 2480530 RF, IPC C22C35 / 00, C21S1 / 10. Ligature for the production of castings from high-strength cast iron (options). / Ageev Yu. A., Shkurkin V.A.; applicant and patent owner: Open Joint-Stock Company "Research Institute of Metallurgy"; claimed. 10.13.2011, publ. 04/27/2013 (in Russian).

[6] Boldyrev, D.A. Osvoenie novyh modifikatorov i tehnologij modifikacii dlja proizvodstva lityh zagotovok na chugunolitejnom zavode OAO «AVTOVAZ» [Mastering of new modifiers and modification technologies for production of cast billets in the iron foundry of JSC AVTOVAZ] [Electronic resource] $\quad$ RAL-Info. $\quad$ Retrieved from http://www.ruscastings.ru/work/168/2130/2968/8460 (in Russian).

[7] Zenkin, R.N., \& Walter A.I. (2014) Modifiers and technologies for secondary treatment of highstrength cast iron. Izvestija Tul'skogo gosudarstvennogo universiteta. Tehnicheskije nauki. Proceedings of Tula State University. Technical science, 11, 30-41.

[8] Zenkin, R.N. .(2014) Mehanizm i raznovidnosti modifikacii vysokoprochnogo chuguna [Mechanism and varieties of modification of high-strength cast iron]. Izvestija Tul'skogo gosudarstvennogo universiteta. Tehnicheskije nauki. - Proceedings of Tula State University. Technical science, 1, 614 (in Russian). 
[9] Himaletdinov, R. Kh. \& V. Ya. Kurovsky (2000) Obrabotka chuguna magniem s ispol'zovaniem briketirovannyh metallicheskih poroshkov [Processing of cast iron with magnesium using briquetted metal powders]. Vestnik mashinostroenija - Bulletin of Machine Building, 3, 41-42 (in Russian).

[10] Pat. 692857 USSR, MKI2 From 21 with 1/00. Graphitizing modifier for processing gray and high-strength cast iron / N.I. Kobelev, I.A. Dibrov at. al. (USSR). - 2509865 / 22-02; claimed. 15.07.77; publ. 25.10.79, Bul. No. 39 (in Russian).

[11] Skorokhod, V.V. (1995) Teorija fizicheskih svojstv poristyh i kompozicionnyh materialov i principy upravlenija ih mikrostrukturoj $\mathrm{v}$ tehnologicheskih processah [The theory of physical properties of porous and composite materials and the principles of controlling their microstructure in technological processes]. Izbrannye raboty - Selected Works (pp. 287-305). Kiev: Powder Metallurgy (in Russian).

\section{МОДЕЛЮВАННЯ РОЗПЛАВЛЕННЯ МД-ВМІСНИХ БРИКЕТІВ, РОЗМІЩЕНИХ У ЛИВАРНІЙ ФОРМІ В ПРЦЕСІ ЛИТТЯ ЧАВУНУ \\ Каверинський В.В., Баглюк Г.А,, Куровський В.Я.}

\section{Реферат}

Методи комп'ютерного моделювання використовувалися для аналізу впливу форми брикетів магнієвмісних модифікаторів, що розміщені в литниковій системі, на час їх плавлення. Моделювання гідродинаміки потоку рідкого металу і теплопровідності проводили методом скінченних елементів. В якості матеріалу виливків приймається доевтектичний чавун, який розливається в прямокутні плити в піщану форму.

Форми брикетів 3 модифікатором наступні: $з$ конічним каналом, який має зовнішній діаметр 40 мм, висоту - 20 мм, діаметр верхнього отвору - 20 мм, діаметр нижнього отвору 34 мм (форма-1); $з$ циліндричним каналом, зовнішній діаметр 40 мм, висота 20 мм і діаметр отвору 24 мм (форма-2); з циліндричним каналом, зовнішній діаметр 40 мм, висота 30 мм, діаметр отвору 29 мм (форма-3); 3 циліндричним каналом, зовнішній діаметр 40 мм, висота 15 мм, діаметр отвору 18,7 мм (форма-4).

Моделювання показує наступні результати. У випадку брикету форми-1, перший контакт металу з модифікатором брикету відбувається через 2,7 секунди від умовного нульового моменту. Брикет починає плавитися через 1,7 с від першого контакту з ним рідкого чавуну, а його плавлення закінчується через 8,3 секунди від першого контакту (тобто 6,6 після початку плавлення). Наповнення порожнини виливки до моменту повного розплавлення брикету становить $25 \%$. Порожнина виливки починає заповнюватись через 4,8 секунди від умовного нульового моменту, і через 0,4 секунди від початку розплавлення брикету. Наповнення порожнини виливки завершується через 28,9 секунд від умовного нульового моменту (час заповнення 24,1 секунди). Повне заповнення порожнини відбувається через 24,5 секунди від початку розплавлення брикету і 17,9 секунди після закінчення його розплавлення. Період існування намороженого шару заліза на поверхні брикету має місце від 3,4 до 7,8 с, тобто триває 4,4 с.

Тонкий брикет (форма-3) починає плавитися відносно рано - через 0,7 секунди. Він плавиться практично без намороженого шару (за результатами моделювання). Але сам процес плавлення триває досить швидко. Доволі тривалий період плавлення має брикет форми-4, але він значно менше, ніж для форми-1. Інші їх характеристики досить схожі. Поведінка брикету форми-2 досить схожа 3 формою-3: швидкий період плавлення, початок плавлення має місце перед самим початком заповнення порожнини, короткий період існування намороженого шару.

Результати моделювання підтверджують і пояснюють отримані експериментальні дані, що форма брикету з конічним отвором дозволяє отримати доволі рівномірний розподіл модифікатора в об'ємі виливки. 


\section{Література}

1. Ржевская С. В. Материаловедение: учебник для вузов / С. В. Ржевская. - Москва: Логос, 2004. $-424 \mathrm{c}$.

2. Кнустад О. Проблемы, возникающие при производстве высокопрочных чугунов. Обзор существующих способов получения ВЧ и используемых модификаторов / О. Кнустад. // Литейщик России. - 2011. - №4. - С. 19-26.

3. Косников Г. А. Основы литейного производства / Г. А. Косников. - Санкт-Петербург: СПбГПУ, 2002. - 204 с.

4. Александров Н. Н. Высококачественные чугуны для отливок / Н. Н. Александров. - Москва: Машиностроение, 1982. -222 с.

5. Пат. 2480530 РФ, МПК С22С35/00, С21C1/10. Лигатура для производства отливок из высокопрочного чугуна (варианты). / Агеев Ю. А., Шкуркин В. А.; заявитель и патентообладатель: открытое акционерное общество "Научно-исследовательский институт металлургии"; заявл. 10.13.2011, опубл. 27.04.2013.

6. Болдырев Д. А. Освоение новых модификаторов и технологий модифицирования для получения литых заготовок в чугунолитейном производстве ОАО «АВТОВАЗ» [Електронний ресурс] / Д. А. Болдырев // РАЛ-Инфо - Режим доступу до ресурсу: http://www.ruscastings.ru/work/168/2130/2968/8460.

7. Зенкин Р. Н. Модификаторы и технологии внепечной обработки высокопрочного чугуна / Р. Н. Зенкин, А. И. Вальтер. // Известия ТулГУ. Технические науки. - 2014. - №11. - С. 30-41.

8. Зенкин Р. Н. Механизм и разновидности модифицирования высокопрочного чугунка. Механизм и разновидности модифицирования высокопрочного чугуна / Р. Н. Зенкин. // Известия ТулГУ. Технические науки. - 2014. - №1. - С. 6-14.

9. Гималетдинов Р. Х. Обработка чугуна магнием с использованием брикетированных металлических порошков / Р. Х. Гималетдинов, В. Я. Куровский. // Вестник машиностроения. 2000. - №3. - C. $41-42$.

10. А. с. 692857 СССР, МКИ2 С 21 С 1/00. Графитизирующий модификатор для обработки серого и высокопрочного чугуна / Н. И. Кобелев, И. А. Дибров, А. В. Козлов, Т. З. Наджмудинов, Б. Л. Постыляков (СССР). - 2509865/22-02; заявл. 15.07.77; опубл. 25.10.79, Бюл. № 39.

11. Скороход В. В. Избранные труды. Теория физических свойств пористых и композиционных материалов и принципы управления их микроструктурой в технологических процессах. // В. В. Скороход, Киев, С. 287 - 305. Порошковая металлургия, 1995, № 1/2. 